\title{
Design of Contextual Teaching and Learning (CTL) Model to Improve Student's Life Skills: The Development Phase in Research and Development
}

\author{
Nurmadiah $^{1}$, Ismail Tolla ${ }^{2}$, Baso Jabu ${ }^{3}$ \\ ${ }^{1}$ Department of Educational Science, Universitas Negeri Makassar \\ Jln. Bonto Langkasa Kampus Gunung Sari Baru, Makassar, South Sulawesi, Indonesia \\ Email: rnurmadiah [AT] gmail.com \\ ${ }^{2}$ Department of Educational Science, Universitas Negeri Makassar \\ Jln. Bonto Langkasa Kampus Gunung Sari Baru, Makassar, South Sulawesi, Indonesia \\ Email: ismail.tolla [AT] yahoo.com \\ ${ }^{3}$ Department of Language and Literature, Universitas Negeri Makassar \\ Jln. Bonto Langkasa Kampus Gunung Sari Baru, Makassar, South Sulawesi, Indonesia \\ Email: basojabu [AT] unm.ac.id
}

\begin{abstract}
One of the teacher's abilities in supporting learning objectives is to design learning products according to the needs in the field. To determine the quality of the developed product, the teacher must conduct several tests involving experts, students, and teachers. This study aims to assess the quality of the learning model that has been developed by researchers, namely the Contextual Teaching \& Learning (CTL) learning model to improve students' life skills through Islamic Religious Education (IRE) subjects. This research is a development phase in research \& development methods focusing on testing the validity, practicality, and effectiveness of the learning model. There were three groups of participants included in this study, namely experts, teachers, and students, who were selected using a purposive sampling technique. Data were collected using several instruments, namely: (1) validation sheets, (2) teacher response questionnaires, and (3) life skills observation sheets. The collected data is then analyzed quantitatively to determine the categories of validity, practicality, and effectiveness. The study results show that the CTL learning model is proven to be valid, practical, and effective in improving the life skills of high school students.
\end{abstract}

Keywords--- Life Skills, Contextual Teaching \& Learning, Islamic Religious Education

\section{INTRODUCTION}

The factors of the development of science and technology, globalization, industrialization in various aspects, privatization, urbanization, and others have a global influence in education [1]. This is considered reasonable because, in essence, education must be flexible to adapt to the times [2]. Although it continues to change, education still has one main goal: to prepare students to become independent and responsible members of society [3].

This shift in the education system, of course, will affect the specific goals of education. Nowadays, education no longer aims to equip students with knowledge alone but also other skills needed in this 21 st century. One of the skills that students must master during the learning process is life skills. Life skills are widely discussed in the public sphere and became popular starting from increasing health problems for the younger generation as part of the world community. UNICEF describes life skills as an alternative behaviour by taking a development approach in three aspects: knowledge, attitudes, and skills [4].

Life skills are a set of psychosocial abilities that enable students to act competently and appropriately, and appropriately in various everyday situations and scenarios [5]. These skills are considered essential for students because they face problems or deficits in personal, cognitive, and social dependence, which are very vulnerable to bullying behaviour, harassment, bullying, drug use and others [6]. [7] state that life skills are the main contributor to negotiating and handling challenges the younger generation faces.

Although the importance of life skills for students' future is an important concept, it is still neglected in the world of 
education now. This fact was found in the United States, as evidenced through a study conducted [8]. This study states that adolescents/adults who have graduated from school/university have only limited knowledge of organising or navigating their lives through real-world expectations. Although several teachers/educational institutions have internalised life skills into the learning process in Indonesia, the results have not been optimal. [9] claims that the role of parents and the school curriculum has not been able to equip the younger generation to face real life.

One of the efforts that can be used to improve students' life skills is to apply appropriate learning strategies. Contextual Teaching \& Learning (CTL) is one of the learning strategies considered capable of improving learning outcomes and other aspects. CTL has improved student achievement and promoted their critical thinking skills and higher-order thinking skills [10]. In addition, CTL is also considered the right approach because it aims to support students in understanding the material by relating it to personal, social, and cultural situations [11].

There are several previous studies related to education and learning to improve students' life skills. A study states that there is a relationship between life skills and students' academic performance [5]. [12] found that strengthening character education through life skills education can be done through a process of self-development and culture in the pesantren environment. Many studies have found that life skills intervention programs into learning can effectively deal with adolescent problems such as self-esteem, decision making, problem-solving, stress, and the influence of drugs [13].

From these several studies, there are still few teachers and researchers interested in developing a CTL learning model focusing on improving students' life skills. Researchers feel it is very important to develop this learning model by integrating it into Islamic Religious Education (IRE) learning for students at the high school level. The formulation of the problem in this study is how the level of validity, practicality, and effectiveness of the CTL learning model in improving students' life skills through Islamic religious education subjects?

\section{LITERATURE REVIEW}

\subsection{Life skills}

Life Skills summarises all the skills and knowledge experienced by a person needed for a useful life. [14] state that life skills are the ability of each individual to adapt and behave positively and appropriately in facing the challenges of everyday life. These skills are learned and acquired to create the conditions for the growth of the individual's behaviour. Furthermore, this definition is strengthened by the [15] statement, which states that life skills are adaptive abilities that enable individuals to face the demands and challenges of the times.

[16] put forward a similar definition, who claims that life skills are a set of human skills acquired through experience and the teaching process used in dealing with the problems encountered. In line with this statement, [17] also argues that life skills are the abilities needed to interact and adapt to other people/communities in the environment in which they are located. Some of the skills referred to include: (1) decision-making skills, (2) problem solving, (3) critical thinking, (4) creative thinking, (5) effective communication, (6) fostering interpersonal relationships, (7) self-awareness, (8) empathy, (9) coping with emotions, and (10) coping with stress $[18,19]$.

Life skills are skills that a person has to be willing and brave to face problems and life naturally without feeling pressured. Based on this definition, [20] identified life skills as an essential resource for developing individual psychosocial, emotional, cognitive, behavioural, and resilience skills to deal with the challenges they face every day. [21] assert that these four skills are essential in ensuring adolescents' personal and social success.

Referring to the article published by the [22] entitled Life Skills Education for Children and Adolescents in Schools about the core or generic life skills, life skills are grouped into three categories. The three categories of life skills are (1) social \& interpersonal skills, (2) cognitive or thinking skills, and (3) emotional skills. However, some experts suggest that the specific types of life skills are: (1) decision making, (2) problem solving, (3) creative thinking, (4) critical thinking, (5) effective communication, (6) interpersonal relationships, (7) self-awareness, (8) empathy, (9) coping with emotions, and (10) coping with stress $[8,9,23,24]$.

\subsection{CTL learning model}

Contextual learning was initially being developed by John Dewey, who formulated a curriculum and learning method related to the experiences and interests of students in 1918. This experiment proved that students would learn well if what they learn is related to the activities/knowledge they already know or occurred in the past. This contextual-based learning approach is the foundation of constructivism philosophy, focusing on learning activities that are not just memorizing abilities [25].

In its development, contextual-based learning has developed and influenced teaching activities in various countries [26]. Learning with this approach has become a standard approach used in almost all fields of education [27]. This is based on the fact that this approach emphasizes that students consider the social context and learning environment to process and process their knowledge [28]. 
Contextual Teaching \& Learning (CTL) is a learning approach that helps students understand what they are learning by connecting the subject matter with the context of their lives [29]. In addition, CTL is also defined as a way to introduce content using a variety of active learning techniques designed to help students relate what they are learning to their environment [30]. Thus, contextual-based learning is an innovative method that places students in a real-life setting and leads to applying the knowledge gained [31].

Experts claim that the CTL approach has various advantages when compared to other methods. Bongancisco (2016) states that students who study with the CTL approach feel the learning process is meaningful because they experience what they learn firsthand. In the CTL approach, students do not only learn by focusing on the memorization aspect alone but more than that. Contextual learning is considered effective in supporting students' academic achievement because this approach involves seven main components of learning, namely: (1) constructivism, (2) asking, (3) investigating, (4) learning community, (5) modelling, (6) reflection, and (7) authentic assessment [32].

The researcher designed this CTL learning model by referring to the learning model proposed by [33]. This learning model consists of several components, namely: (1) syntax, (2) social system, (3) reaction principle, (4) support system, and (5) instructional impact \& accompaniment. Some of the learning products developed in this study include (1) model books, (2) teacher handbooks, (3) student handbooks, (4) Semester Lesson Plan (SLP), and (5) Student Worksheets (SW).

\subsection{Islamic religious education (IRE)}

[34] gives an understanding of Islamic education as an effort that is more specifically emphasized to develop students' religious nature (religiosity) so that they are better able to understand, appreciate, and practice Islamic teachings. Implementing this understanding, Islamic Religious Education (IRE) is an inseparable component of the Islamic education system. It is not an exaggeration to say that Islamic education functions as a pathway for integrating Islamic religious insight with other fields of study.

The term Islamic education can be understood in several senses. First, Islamic education is education that is understood and developed from the teachings and fundamental values contained in its primary sources, namely the Qur'an and AlSunnah. Second, Islamic religious education is an effort to educate Islamic values to become the views and attitudes of one's life. Finally, IRE is a process and practice of providing education that has taken place and developed in the history of Muslims. Although the term IRE can be understood differently, in essence, it is a unit that cannot be separated into one complete system [35].

In addition, IRE is also interpreted as a conscious effort to prepare students to believe, understand, appreciate, and practice the teachings of the Islamic religion through reality, guidance, teaching, and training by paying attention to the demands to respect others faiths [36]. In line with this definition, [37] states that IRE is a form of education that provides knowledge and shapes the attitudes, personality, and skills of students in practising their religious teachings, which is carried out at least through subjects/lectures at all paths, levels, and type of education.

\section{METHODS}

\subsection{Research design}

In designing a product in the form of a CTL learning model in IRE subjects, researchers used the Four-D theory proposed by [38]. This theory consists of four main stages of research, namely define, design, develop, and disseminate. In this article, the main focus discussed is the development phase which contains three main activities in measuring the quality of the product created. The three tests in this development phase are validity, practicality, and effectiveness tests [39].

A validity test is conducted by researchers involving several experts in their fields to measure, assess, and provide suggestions for the products developed. Furthermore, the practicality test is a product trial by applying users in assessing the level of practicality. Finally, the product effectiveness test is a specific test involving students to see learning outcomes using the CTL learning model that has been developed.

\subsection{Research site and participants}

The practicality and effectiveness were conducted at the State Senior High School (SMAN) 22 Makassar, Indonesia. The selection of this research location was based on the fact that the school was more representative for research purposes when compared to other schools. There were 20 students involved in this study which came from class X. The selection of this research subject used the purposive sampling technique, which is a sampling technique based on specific needs and considerations.

\subsection{Data collection}

\subsubsection{Product validation sheet}

To test product validity used was a product validation sheet was developed by the researcher. There are four types of validation sheets used, namely: (1) model book validation sheets, (2) teacher handbook validation sheets, (3) student book validation sheets, (4) student worksheets (SW), and (5) Semester Learning Plan (SLP). The validation sheet is designed by providing four score options, namely a score of $4=$ very valid, $3=$ valid, $2=$ less valid, and $1=$ invalid. Several aspects assessed in the product validation sheet are presented in table 1. 
Table 1. Aspects assessed in the validity test

\begin{tabular}{lll}
\hline No. & Validated product & Validated Aspects \\
\hline $\mathbf{1 .}$ & Model book & Model rationality \\
& & Supporting theory \\
& & Model description \\
& & Implementation of learning \\
& & Learning environment and learning tasks \\
\hline $\mathbf{2 .}$ & Teacher's handbook & Format \\
& & Illustration \\
& & Aspects of language \\
\hline 3. & Student Books & Content aspects \\
& & Format \\
& & Illustration \\
\hline 4. & Semester Learning Plan (SLP) & Aspects of language \\
& & Content aspects \\
\hline $\mathbf{5 .}$ & Student Worksheets (SW) & Aspects of format \\
& & Aspects of language \\
& & Content aspects \\
\hline
\end{tabular}

3.3.2 Product practicality questionnaire for teachers

To measure the product's practicality, the researcher distributed a questionnaire to the teachers to assess the research product that had been developed. The developed questionnaire consists of several questions by providing four answer options, namely: (a) very helpful, (b) helpful, (c) less helpful, and (d) not helpful.

\subsubsection{Student life skills observation sheet}

To measure the effectiveness of this learning model, the researcher used a life skills observation sheet filled out by the teacher as an observer. The life skills observation sheet uses an attitude scale instrument adapted from a questionnaire developed by [40]. This observation sheet is designed by incorporating two elements of life skills, namely personal skills and social skills. There are two forms of statements (favourable \& unfavourable) in the instrument using a Likert scale, as shown in Table 2.

Table 2. Scores of respondents' alternative answers

\begin{tabular}{llll}
\hline No. & & Score & \\
\cline { 3 - 4 } & Category & Favourable & Unfavourable \\
\hline 1. & Strongly Agree & 4 & 1 \\
2. & Agree & 3 & 2 \\
3. & Less Disagree & 2 & 3 \\
4. & Disagree & 1 & 4 \\
5. & Strongly Disagree & 5 \\
\hline
\end{tabular}

\subsection{Data analysis}

Data from two experts, and three teachers were analyzed quantitatively to determine the average score. After obtaining the average score, the results of the validation/practicality are compared with the criteria listed in table 3.

Table 3. Criteria for validity and student responses [41].

\begin{tabular}{ll}
\hline Score interval & Rating Category \\
\hline $3.6 \leq \mathrm{M} \leq 4$ & Very Valid/Very Practical \\
\hline $2.6 \leq \mathrm{M} \leq 3.5$ & Valid/Practical \\
\hline $1.6 \leq \mathrm{M} \leq 2.5$ & Less Valid/Less Practical \\
\hline $1.0 \leq \mathrm{M} \leq 1.5$ & Invalid/Impractical \\
\hline
\end{tabular}

Furthermore, the observation data from the teachers to determine the level of effectiveness were also analyzed quantitatively to determine the overall percentage of student activity. After the percentage score is obtained, it is then compared with the effectiveness category to choose whether the level of student life skills is very high, high, medium, less, or inferior. 


\subsection{Validity of ctl learning model}

\section{RESEARCH RESULTS}

To determine the level of product validity, researchers provide validation sheets to experts to assess the product. There are two types of validated products, namely model books and learning tools. Validated learning tools are teacher handbooks, student books, Semester Learning Plan (SLP), and Student Worksheets (SW). The validation results can be seen in table 4 .

Table 4. Results of the validation of the CTL learning model

\begin{tabular}{llll}
\hline No & Validation instrument & Average score & Category \\
\hline 1. & Learning model book & 3.53 & Very Valid \\
\hline 2. & Teacher's handbook & 3.37 & Valid \\
\hline 3. & Student book & 3.38 & Valid \\
\hline 4. & Semester Lesson Plan (SLP) & 3.56 & Very Valid \\
\hline 5. & Student Worksheet (SW) & 3.24 & Valid \\
\hline
\end{tabular}

Based on table 4, the validation results of the model book and learning tools are declared "valid" and "very valid". Learning products categorized as very valid are model books with an average score of 3.53 and lesson plans with an average score of 3.56. In addition, the three learning products that were declared "valid" based on the experts' assessments were the teacher's handbook, student's book, and worksheets. The validation results of the teacher's handbook reached an average score of 3.37, the student book was 3.38, and the Student Worksheet (LKS) was 3.24. Thus, model books and other learning tools are usable with slight improvements based on expert judgment.

\subsection{Practicality of ctl learning model}

The level of practicality of this CTL model is determined based on the responses given to teachers who assess the overall model book and learning tools developed. In general, the results of the average practicality level of the CTL learning model are presented in table 5 .

Table 5. The results of the analysis of the practicality of the CTL learning model

\begin{tabular}{|c|c|c|c|}
\hline No. & Assessment Aspects & Average & Category \\
\hline \multicolumn{4}{|c|}{ Do these learning tools help improve students' life skills? } \\
\hline $\begin{array}{l}1 . \\
2 . \\
3 . \\
4 . \\
5 . \\
6 . \\
7\end{array}$ & $\begin{array}{l}\text { Material Analysis } \\
\text { Competency Map } \\
\text { Lesson plan } \\
\text { Textbooks } \\
\text { Student Book } \\
\text { Student Worksheet } \\
\text { Learning Activities }\end{array}$ & $\begin{array}{l}4.0 \\
3.0 \\
3.0 \\
4.0 \\
3.0 \\
4.0 \\
3.0\end{array}$ & $\begin{array}{l}\text { Very Practical } \\
\text { Practical } \\
\text { Practical } \\
\text { Very Practical } \\
\text { Practical } \\
\text { Very Practical } \\
\text { Practical }\end{array}$ \\
\hline $\begin{array}{l}\text { Is th } \\
8 . \\
9 . \\
10 . \\
11 . \\
12 . \\
13 . \\
14 .\end{array}$ & $\begin{array}{l}\text { rning tool categorized as good? } \\
\text { Material Analysis } \\
\text { Competency Map } \\
\text { Lesson plan } \\
\text { Textbooks } \\
\text { Student Book } \\
\text { Student Worksheet } \\
\text { Learning Activities }\end{array}$ & $\begin{array}{l}4.0 \\
3.0 \\
3.5 \\
4.0 \\
3.0 \\
4.0 \\
4.0\end{array}$ & $\begin{array}{l}\text { Very Practical } \\
\text { Practical } \\
\text { Very Practical } \\
\text { Very Practical } \\
\text { Practical } \\
\text { Very Practical } \\
\text { Very Practical }\end{array}$ \\
\hline \multicolumn{4}{|c|}{ Additional Description } \\
\hline 15. & $\begin{array}{l}\text { Is this learning tool necessary and feasible to be } \\
\text { developed on other subjects? }\end{array}$ & 4.0 & Very Practical \\
\hline 16. & $\begin{array}{l}\text { Is this learning model by the pattern of education } \\
\text { and training (training) }\end{array}$ & 3.0 & Practical \\
\hline 17. & $\begin{array}{l}\text { Is this learning model by the procedures in the } \\
\text { device development workshop? }\end{array}$ & 3.0 & Practical \\
\hline 18. & $\begin{array}{l}\text { Can this learning model be used as a learning } \\
\text { model in IRE learning activities in the future? }\end{array}$ & 3.0 & Practical \\
\hline 19. & $\begin{array}{l}\text { What obstacles were encountered during the } \\
\text { learning process? }\end{array}$ & 3.5 & Very Practical \\
\hline 20. & $\begin{array}{l}\text { In your opinion, what are the advantages of } \\
\text { implementing this learning model? }\end{array}$ & 3.0 & Practical \\
\hline Tot: & rage & 3.5 & Very Practical \\
\hline
\end{tabular}


From table 5 above, information is obtained that this learning model is classified as very practical overall. This is obtained from the teacher's response analysis in assessing the learning products that have been developed. Overall, the average score of the teacher's response questionnaire is 3.5 and is categorized as very practical. The very practical category was concluded from the average score, which was in the score range of $3.5 \leq \mathrm{M} \leq 4.0$. Thus, the CTL learning model in IRE subjects is proven to be practical in terms of its use based on the teachers' assessment.

\subsection{Results of model effectiveness analysis}

During the learning process, three observers made observations to assess students' life skills. Overall, the results of the student's life skills are presented in Table 6 and Table 7.

Table 6. Distribution of students' life skills observations

\begin{tabular}{lllll}
\hline No & Score & Frequency $(\mathbf{f})$ & $\mathbf{f . x}$ & Percentage (\%) \\
\hline 1. & 66 & 1 & 66 & 6.66 \\
2. & 69 & 3 & 207 & 20 \\
3. & 70 & 1 & 70 & 6.66 \\
4. & 72 & 2 & 144 & 13.3 \\
5. & 75 & 3 & 225 & 20 \\
6. & 76 & 2 & 152 & 13.3 \\
7. & 77 & 1 & 77 & 6.66 \\
8. & 79 & 1 & 79 & 6.66 \\
9. & 80 & 1 & 80 & 6.66 \\
\hline
\end{tabular}

Table 7. Student life skills achievement categories

\begin{tabular}{lllll}
\hline No. & Score interval & Category & Frequency & Percentage (\%) \\
\hline 1. & $79-83$ & Very high & 2 & $13 \%$ \\
2. & $74-78$ & high & 6 & $40 \%$ \\
3. & $70-73$ & Moderate & 3 & $20 \%$ \\
4. & $66-69$ & Low & 4 & $27 \%$ \\
\hline & & & 15 & $100 \%$ \\
\hline
\end{tabular}

From the results of the student's life skills scores, they can be grouped into several categories. Two students achieved scores between 79 to 83 and were categorized as very high. Furthermore, six students are in the high category, with $40 \%$ of the total number of students. For the medium category, three students fall into this category (20\%), while the other four students are in the low category with $27 \%$.

\section{DISCUSSION}

This study indicates that the CTL learning model in Islamic Religious Education learning is proven to be valid, practical, and effective in improving the life skills of high school students. The three tests are tests carried out to see the level of validity, practicality, and effectiveness of the learning products that have been developed [42]. Product validity is determined by the expert's assessment of the developed product, which usually validates two aspects, namely construct validity and content [43]. In this study, several aspects are assessed in the validation process, namely: (1) content aspects, (2) language, (3) format, and others. However, [44] stated that the aspects assessed in product validity were adequacy, suitability, coherence, and usability.

In addition to the validity test, practicality tests also need to be carried out in measuring the quality of learning products. This practicality test is a test that involves users providing responses related to products that have been developed. A product is declared practical if it meets several criteria. It namely (a) the teacher's assessment states that the product can be applied due to slight revisions; (b) the product can be applied in the classroom by the applicable curriculum, time allocation, and others [45].

The final test in determining the quality of product development is the effectiveness test. This test involves students as users by looking at the effect produced by the product on the specified target, cognitive aspects (learning outcomes), attitudes (affective), and skills. [46] tated that the effectiveness of the product is determined by several criteria, namely: (a) the achievement of predetermined goals, (b) according to the needs of users, and (c) having a positive impact on improving learning outcomes, both in terms of aspects knowledge, attitudes, and behaviour.

Life skills as one of the skills to be achieved through education have become the reference and goal of education from preschool, elementary school, high school to college level. Life skills training and education puts students on the highway to development and enables them to live life efficiently and successfully [18]. But basically, life skills play a significant 
role in increasing a person's psychological and physical well-being, influenced by various social and environmental factors $[47,48]$.

In the learning process in the classroom, of course, the right strategy or method is needed so that students' life skills can be grown and developed correctly. Life skills education involves a dynamic learning process built with social learning theory [49] This study uses a Contextual Teaching \& Learning (CTL) approach, which is a fundamental approach in promoting student life skills. This method is considered the best method because it includes several activities that include cooperative learning, problem-based learning, work-based learning, project-based learning, and service-learning [10].

In addition, life skills also play a role in influencing certain aspects of human life. A study shows that life skills in deaf students can increase their self-esteem in the classroom [50]. On the other hand, life skills can also be associated with positive determinants of improving student learning skills [51]. Life skills connect factors that drive knowledge, attitudes, values and positive behaviour on health aspects. The two researchers claim that life skills contribute to the process of primary education, democracy, character building, continuous learning, and quality of life [52].

By seeing the many advantages of these life skills, teachers should design learning models that can improve these skills. This study is expected to be used as a basis and consideration for policymakers in Indonesia to focus on improving students' life skills. This means that teachers/researchers and the government must synergize in designing educational curricula that highlight life skills rather than just focusing on learning test results that are more inclined to the cognitive aspect alone.

\section{CONCLUSION}

This research is the "develop" phase of the research and development method of 4D theory from Thiagarajan et al. (1974), which aims to determine the level of validity, practicality, and effectiveness of the CTL learning model in PAI learning to improve students' life skills. The results showed that the products produced were proven to be valid, practical, and effective. Product development in a learning model is deliberately focused on aspects of life skills as 21 st-century skills that students must master. Life skills must be a priority in the educational curriculum design because, with these skills, students can learn through their environment and overcome the problems of everyday life.

\section{REFERENCES}

1. Prajapati R, Sharma B, Sharma D. Significance of life skills education. Contemporary Issues in Education Research (CIER). 2016;10(1):1-6.

2. Helaluddin H. Restrukturisasi Pendidikan Berbasis Budaya: Penerapan Teori Esensialisme di Indonesia. Jurnal Dimensi Pendidikan \& Pembelajaran. 2018 Jul 20;6(2):74-82.

3. Meier C, Naude M. Teaching life skills in the foundation phase. Van Schaik: Pretoria; 2017.

4. Saravanakumar AR. Life skill education for creative and productive citizens. Journal of Critical Reviews. 2020;7(9):554-8.

5. Sanchez-Hernando B, Juarez-Vela R, Anton-Solanas I, Gasch-Gallen Á, Melo P, Nguyen TH, et al. Association between life skills and academic performance in adolescents in the autonomous community of Aragon (Spain). International Journal of Environmental Research and Public Health. 2021;18(4288):1-12.

6. Nasheeda A, Abdullah HB, Krauss SE, Ahmed NB. A narrative systematic review of life skills education: Effectiveness, research gaps and priorities. International Journal of Adolescence and Youth. 2019;24(3):362-79.

7. Savoji AP, Ganji K. Increasing mental helath of university students through life skills training (lst). Procedia Social and Behavioral Sciences. 2013;84:1255-9.

8. Cassidy K. Preparation for adulthood: A teacher inquiry study for facilitating life skills in secobdary education in United States. Journal of Educational Issues. 2018;4(1):33-45.

9. Wairimu KH. Factors influencing implementation of life skills education in primary schools in Starehe subcountry. Kenya: Nairobi; 2015.

10. Berns RG, Erickson PM. Contextual teaching and learning: Preparing students for the new economy. Career and Technical Education Technology. 2001;5(1):1-9.

11. Sears S. Introduction to contextual teaching and learning. Indiana: The Phi delta kappa Educational Foundation; 2003.

12. Defitrika F, Mahmudah FN. Development of life skills education as character building. International Journal of Educational Management and Innovation. 2021;2(1):116.

13. Parvathy V, Pillai RR. Impact of life skills education on adolescence in rural school. International Journal of Advanced Research. 2015;3(2):788-94. 
14. Gerami S, Ahmadi S, Safat MB, Farsi F. Life skills training and its effectiveness: A systematic review. Mediterranean Journal of Social Sciences. 2015;6(2):385-92.

15. World Health Organizaton. Kife skills education for children and adolescence in school: Programme on mental health. WHO; 1993.

16. Behera AK. Life skill education in classroom. International Journal of Humanities and Social Science Invention. 2020;9(8):4-10.

17. Anwar A. Pendidikan kecakapan hidup. Bandung: Alfabeta; 2015.

18. Saravakumar AR, Devi PKR. Indian higher education: Issues and opportunities. Journal of Critical Reviews. 2020;7(2)

19. Kackar A, Joshi H. Impact of life skills among adolescents: A review. International Journal of Research and Analytical Reviews. 2012;6(2):592-5.

20. Galagali PM. Adolescence and life skills. In: Olyai R, Dutta DK, editors. Recent advances in adolescent health. New Delhi: JAYPEE Brothers Medical Publisher; 2011. p. 209-18.

21. Langford BH, Badeau SH, Legters L. Investing to improve the well-being of vulnerable youth and young adults: Recommnedations for policy and practice [Internet]. 2015 [cited 2021 Aug 30]. Available from: http://www.yttg.org/2017/12/wellbeing/

22. World Health Organizaton. Life skills education for children and adolescents in schools. Geneva: WHO; 1997.

23. Precious Z, Racheal S. Life skills education for enhancement of learners' wellness in Eswatini: A case of high school learners in Shiselweni Region. Journal of Resources Development and Management. 2019;59(1):44-50.

24. Morales-Rodriguez M, Benitez-Hernandez M, Agustin-Santos D. Life skills (cognitive and social) in teenagers in a rural area. Revista Electronica de Investigacion Educative. 2013;15(3):98-113.

25. Suryawati E, Osman K. Contextual learning: Innovative approach towards the development of students' scientific attitude and natural science performance. Eurasia Journal of Mathematics, Science and Technology Education. 2018;14(1):61-76.

26. Dori YJ, Avargil S, Kohen Z, Saar L. Context-based learning and metacognitive prompts for enhancing scientific text comprehension. International Journal of Science Education. 2018;40(10):1198-220.

27. Podschuweit S, Bernholt S. Compositon effects of context-based learning opportunities on students' understanding of energy. Research in Science Education. 2018;48(4):717-52.

28. Yu KC, Fan SC, Lin KY. Enhancing students' problem solving skills through context based learning. International Journal of Sciences and Mathematics Education. 2015;13(6):1377-401.

29. Johnson EB. Contextual teaching and learning. California: Corwin Press. Inc; 2002.

30. Hudson CC, Whisler VR. Contextual teaching and learning for practitioners. Journal of Systemics, Cybernetics and Informatics. 2008;6(4):54-8.

31. Ozka O, Gercek C. What are the pre-service physics teachers' opinion about context based approach in physics lessons? Procedia-Social and Behavioral Sciences. 2015;197:892-7.

32. Sanjaya W. Kurikulum dan pembelajaran Teori dan praktik: Kurikulum tingkat satuan pendidikan (ktsp). Jakarta, Indonesia: Kencana Prenada Media Group; 2011.

33. Joyce B, Weil M, Calhoun E. Models of Teaching (Model-Model Pembelajaran). Yogyakarta: Pustaka Pelajar; 2011.

34. Achmadi A. Ideologi pendidikan Islam: Paradigma humanisme teosentris. Yogyakarta, Indonesia: Pustaka Pelajar; 2010.

35. Muhaimin M. Paradigma pendidikan Islam: Upaya mengefektifkan pendididkan agama Islam di sekolah. Bandung, Indonesia: Remaja Rosdakarya; 2008.

36. Rahman AS. Pendidikan agama dan keagamaan, visi, misi, dan aksi. Jakarta, Indonesia: Gema Windu Panca Perkasa; 2000.

37. Muslich M. Pembelajaran berbasis kompetensi dan kontekstual. Malang, Indonesia: Bumi Aksara; 2012.

38. Thiagarajan S, Semmel DS, Semmel MI. Instructional Development for Training Teachers of Exceptional Children. Blomington Indiana: Indiana University; 1974. 
39. Nieveen N. Prototyping to Reach Product Quality. In: Plomp T, Nieveen N, Gustafson K, Branch RM, Akker V Den, editors. Design Approach and Tools in Education \& Training. London: Kluwer Academic Publisher; 1999.

40. Goleman D. Working with emotional intelligence. Jakarta, Indonesia: Gramedia Pustaka Utama; 2000.

41. Supartini T, Weismann IThJ, Wijaya H, Helaluddin Helaluddin. Development of Learning Methods through Songs and Movements to Improve Children's Cognitive and Psychomotor Aspects. European Journal of Educational Research. 2020;9(4):1615-33.

42. Nieveen N. Prototyping to Reach Product Quality. In: Akker J Van Den, Branch RM, Gustafson K, Nienke Nieveen, editors. Design Approaches and Tool in Education and Training. Boston: Kluwer; 1999.

43. Muhali M, Yuanita L, Ibrahim M. The Validity and Effectiveness of the Reflective-metacognitive Learning Model to Improve Students' Metacognition Ability in Indonesia. Malaysian Journal of Learning and Instruction. 2019;16(2):33-74.

44. Rogayan Jr. D V., Dollete LF. Development and Validation of Physical Science Workbook for Senior High School. Science Education International. 2019;30(4):84-290.

45. Jaedun A, Hariyanto VL, Raharjo NE. Pengembangan Model Pembelajaran Produktif Bermuatan Kewirausahaan. Jurnal Kependidikan. 2017;1(1):125-38.

46. Chiang CL, Lee H. The Effect of Project-Based Learning on Learning Motivation and Problem-Solving Ability of Vocational High School Students. International Journal of Information and Education Technology. 2016;6(9):70912.

47. Cronin LD, Allen J. Development and initial validation of the life skills scale for sport. Psychology of Sport and Exercise. 2017;28:105-19.

48. Maddah D, Saab Y, Safadi H, Abi Farraj N, Hassan Z, Turner S, et al. The first life skills intervention to enhance well-being amongst university students in the Arab world: 'Khotwa' pilot study. Health Psychology Open. 2021;8(1):1-14.

49. Nagaraju MTV. Strategies to promote life-skills among adolescents. European Journal of Education Studies. 2016;2(3):112-9.

50. Vernosfaderani AM. The effectiveness of life skills training on enhancing the self-esteem of hearing impaired students in inclusive schools. Open Journal of Medical Psychology. 2014;3(1):94-9.

51. Daisy PJ, Nair AR. An exploratory study on life skills intervention and its impact on the study skills among young adolescents. International Journal of Innovations in Engineering and Technology. 2018;10(3):14-20.

52. Chan JCA, Briceno ED. Life skills in higher education: An innovative proposal. International Journal of Arts and Social Science. 2019;2(2):10-8. 